\begin{tabular}{|c|c|}
\hline 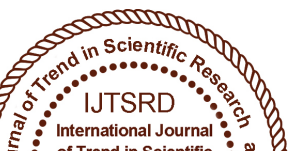 & $\begin{array}{l}\text { International Journal of Trend in Scientific } \\
\text { Research and Development (IJTSRD) }\end{array}$ \\
\hline 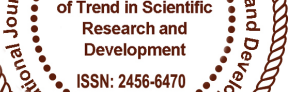 & International Open Access Journal \\
\hline 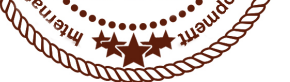 & ISSN No: 2456 - 6470 | www.ijtsrd.com | Volume - 2 | Issue - 5 \\
\hline
\end{tabular}

\title{
Modeling and Simulation of Bevel Gearboxes in AutoCAD
}

\author{
Potnuru Sandeep, Rajesh C V S \\ Assistant Professor, Department of Mechanical Engineering, \\ Vizag Institute of Technology, Visakhapatnam, Andhra Pradesh, India
}

\section{ABSTRACT}

Designing and developed of aeronautic bevel gearboxes is a complex and time-consuming method. A gear or cogwheel is a rotating machine part having cut like teeth, or cogs, which mesh with another toothed part to transmit torque. Geared devices can change the speed, torque, and direction of a power source. Gears almost always produce a change in torque, creating a mechanical advantage, through their gear ratio, and thus may be considered a simple machine. The teeth on the two meshing gears all have the same shape. Two or more meshing gears, working in a sequence, are called a gear train or a transmission. A gear can mesh with a linear toothed part, called a rack, producing translation instead of rotation. This is due to the high class necessities to the aviation industry products and the compound kinematic of the machining process. So far, in practice, this procedure has essential a series of study and prototypes testing. The improvement, has been made in the field of Computer Aided Design environment, allows growing use in design method and carries out the required research in the CAD environment. This approach simplifies and accelerates the aeronautic bevel gearboxes design development.

\section{INTRODUCTION}

The principle of CAD environment in bevel gearboxes design method enables to bring out a preliminary learning in order to confirm them both in terms of manufacturing technology along with accuracy of bevel gearbox cooperation. The analysis in the CAD environment agrees to to find out the temporary and review tooth bearing as well as obtain movement graphs. Provisional and synopsis tooth bearings were obtained by performing geometric investigation of gearbox cooperation. In categorize to acquire provisional bearing; there were assembled tangentially cooperating gears surfaces. A gear or cogwheel is a rotating machine part having cut like teeth, or cogs, which mesh with another toothed part to transmit torque. Geared devices can change the speed, torque, and direction of a power source. Gears almost always produce a change in torque, creating a mechanical advantage, through their gear ratio, and thus may be considered a simple machine. The teeth on the two meshing gears all have the same shape.[1] Two or more meshing gears, working in a sequence, are called a gear train or a transmission. A gear can mesh with a linear toothed part, called a rack, producing translation instead of rotation. In after that step, to acquire bearing, solid of pinion was moved into gear solid by a space resulting from the resilient strain of cooperating gears. As a effect of Boolean meeting point operation obtained temporary bearing.

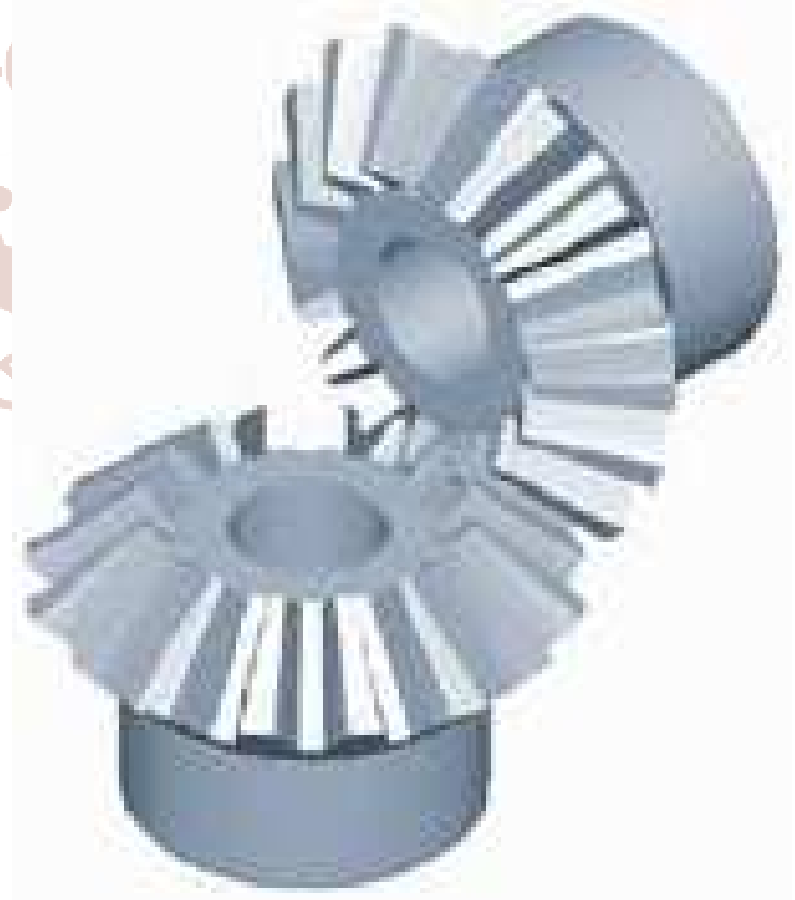

Bevel gearbox solid model construction 


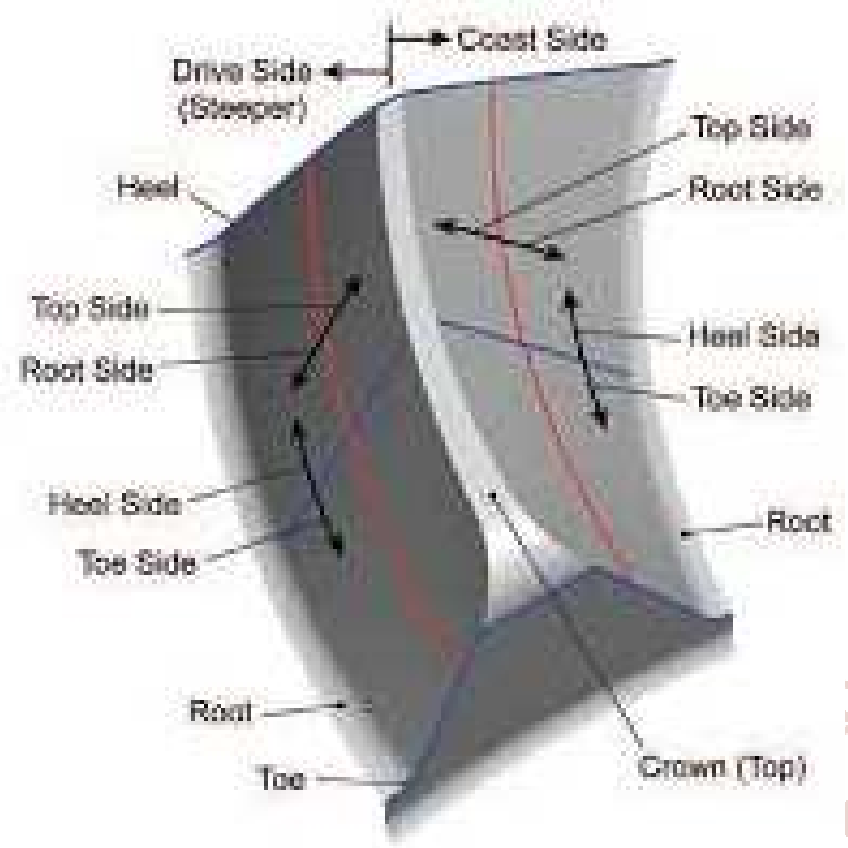

Synopsis bearing on the gear tooth flank

Bevel gears are gears where the axes of the two shafts intersect and the tooth-bearing faces of the gears themselves are conically shaped. Bevel gears are most often mounted on shafts that are 90 degrees apart, but can be designed to work at other angles as well. [1] The pitch surface of bevel gears is a cone.

Two important concepts in gearing are pitch surface and pitch angle. The pitch surface of a gear is the imaginary toothless surface that you would have by averaging out the peaks and valleys of the individual teeth. The pitch surface of an ordinary gear is the shape of a cylinder. The pitch angle of a gear is the angle between the face of the pitch surface and the axis.

The most familiar kinds of bevel gears have pitch angles of less than 90 degrees and therefore are coneshaped. This type of bevel gear is called external because the gear teeth point outward. The pitch surfaces of meshed external bevel gears are coaxial with the gear shafts; the apexes of the two surfaces are at the point of intersection of the shaft axes.

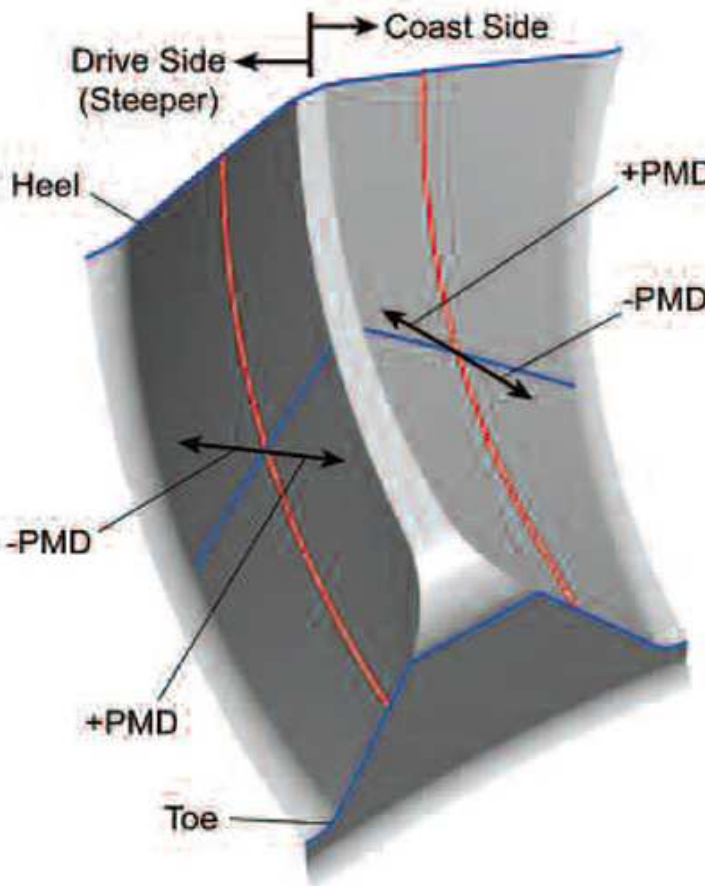

Synopsis bearing on the gear tooth flank

Generating a contact path and line of action requires the purpose of geometric center points of provisional bearings. Purpose of center points of bearings obtained on the bevel gearboxes gears surfaces is troublesome because the geometric difficulty of the surfaces. The extra element is bonded with the inner flank of the gear tooth and the outer flank of the pinion tooth surface with the tangency constraint. Flank surfaces of the teeth and surface of the intermediary component, connected in this way, have only one general point.

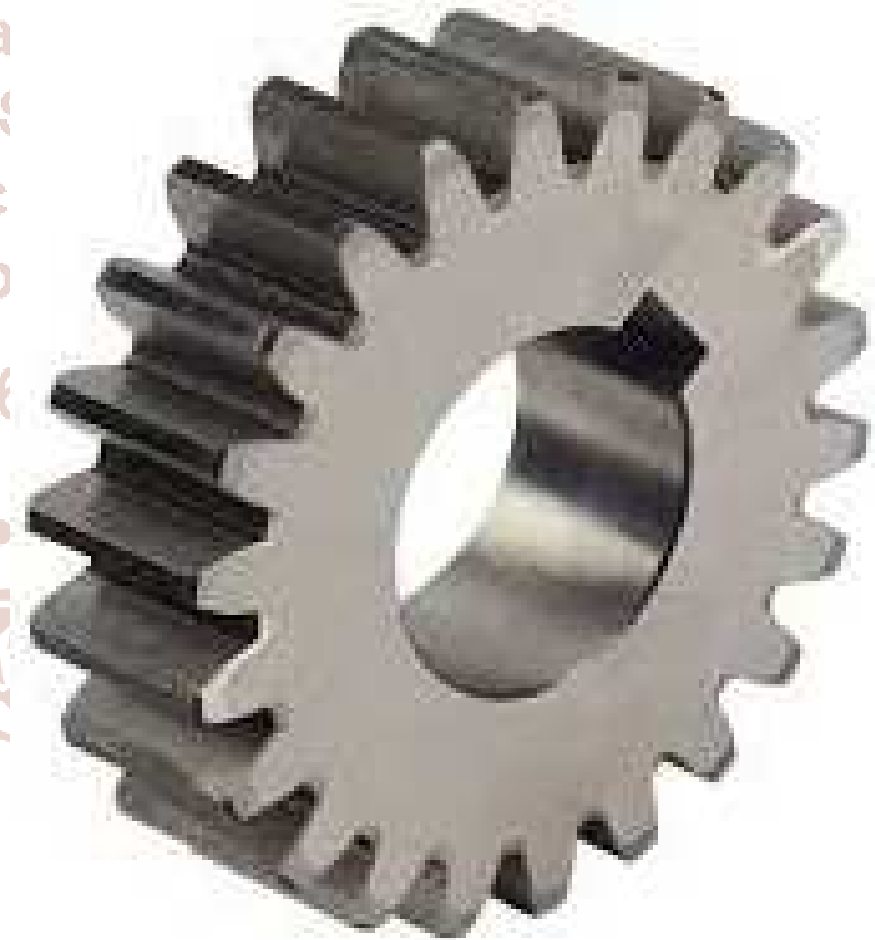

Examination of the bevel gearbox collaboration with the intermediate element

Gathering of assembly gearbox, connected in the method described above, maintains mobility. Generating on its foundation the contact line on the teeth surfaces and the line of action is based on recording the path of the provisional bearing center point in the appropriate coordinate system. 


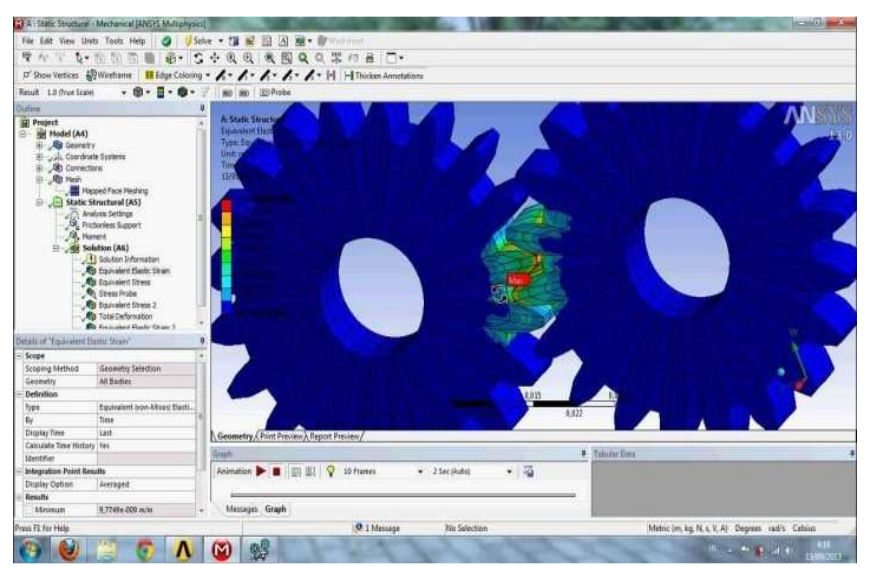

/ layout like the conventional manufacturing method. Simplified calculated bevel gears on the basis of an equivalent cylindrical gear in normal section with an involute tooth form show a deviant tooth form with reduced tooth strength by $10-28 \%$ without offset and $45 \%$ with offset [Diss. Hünecke, TU Dresden]. Furthermore, those "involute bevel gear sets" causes more noise.

\section{ACKNOWLEDGMENT}

In this research paper of using CAD environment in modeling and analysis of bevel gearboxes of Gleason system show the usefulness of these methods in the process of design.

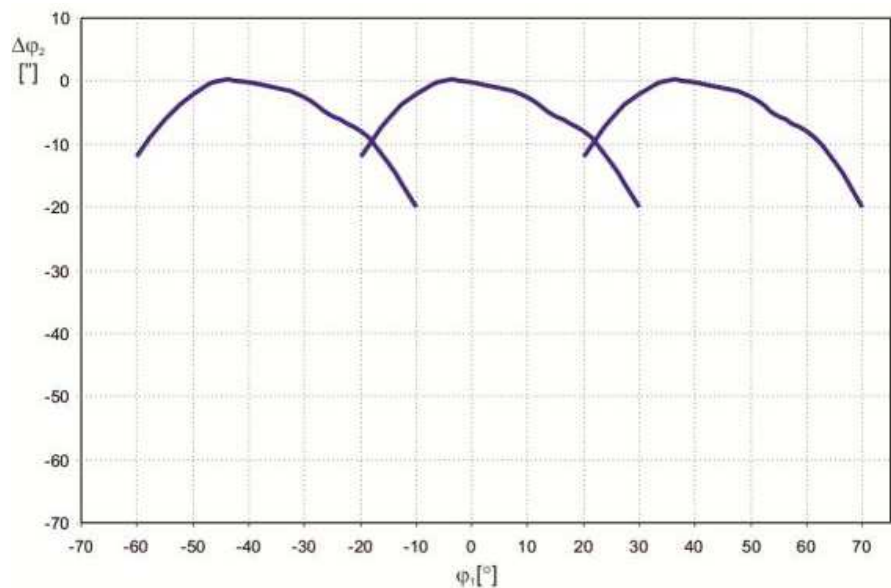

Ideal motion diagram

The cylindrical gear tooth profile corresponds to an involute (i.e. a triangle wave projected on the circumference of a circle), whereas the bevel gear tooth profile is an octoid (i.e. a triangle wave projected on the normal path of a circle of a sphere). All traditional bevel gear generators (such as Gleason, Klingelnberg, Heidenreich \& Harbeck, WMW Modul) manufacture bevel gears with an octoidal tooth profile. IMPORTANT: For 5-axis milled bevel gear sets it is important to choose the same calculation

\section{REFERENCES}

1. Skawiński P.: Technological setups of the Gleason CNC spiral bevel and hypoid gear milling machines; Advances in manufacturing Science and Technology, Vo.36, No.4, 2012, str. 33-43

2. Sobolak M.: Analiza i synteza współpracy powierzchni kół zębatych metodami dyskretnymi. Oficyna Wydawnicza Politechniki Rzeszowskiej, Rzeszów 2006.

3. Litvin F. L., Qi Fan, Fuentes A. (2001), "Computerized Design, Generation, Simulation of Meshing and Contact of Face-Milled Formate Cut Spiral Bevel Gears", NASA/CR-2001

4. Stadtfeld H. J (1999)," The universal motion concept for bevel gear production", paper presented at "Gearing and Power Transmission", 1999, Paris 